\title{
Structural Factors Affecting the Number and Cost of Personal Injury Claims in the Tort System
}

\author{
Richard Lewis $^{1}$
}

This chapter examines Britain's “compensation culture." This is one of the terms most frequently used by the media today when discussing claims for damages for personal injury. ${ }^{2}$ The expression has a variety of meanings but here we focus upon the allegation that society has had to bear an increasing burden as a result of the rising number and cost of these claims. Rather than celebrating greater access to the legal system whereby the needs of those injured are more likely to be met, the predominant view of the culture is a negative one: it is alleged that unwarranted claims have been

\footnotetext{
${ }^{1}$ Professor of Law at Cardiff University. Email: LewisRK@Cardiff.ac.uk
}

For their comments on an earlier and shorter draft published as 'Compensation Culture Reviewed' in [2014] JPIL 209 I wish to thank Kevin Williams and the participants at the conference organised at the University of Limerick which stimulated the production of this book.

${ }^{2}$ For discussion of compensation culture in academic publications see J. Spencer, 'An Unethical Personal Injury Sector' [2014] JPIL 226, L. O’Sullivan, 'Money For Nothing and Cheques For Free? Negligence and the Perceived "Compensation Culture”" (2014) 2(1) UK Law Student Review 74, A. Morris, 'The Compensation Culture and the Politics of Tort' in T. T. Arvind and J. Steele (eds), Tort and the Legislature: Common Law, Statute and the Dynamics of Legal Change (Oxford: Hart Publishing, 2012), R. Lewis and A. Morris, ‘Tort Law Culture: Image and Reality' (2012) 39 J Law \& Society 562, J. Ilan 'The Commodification of Compensation: Personal Injury Claims in an Age of Consumption' (2011) 20 Social \& Legal Studies 39, J. Hand, 'The Compensation Culture: Cliché or Cause for Concern?' (2010) 37 J Law \& Society 569, A. Morris, 'Spiralling or Stabilising? The Compensation Culture and our Propensity to Claim Damages for Personal Injury' (2007) 70 Modern Law Rev 349, R. Lewis, A. Morris and K. Oliphant, 'Tort Personal Injury Statistics: Is There a Compensation Culture in the UK?' (2006) 14 Torts Law J 158 and [2006] JPIL 87, K. Williams, 'State of Fear: Britain's “Compensation Culture” Reviewed' (2005) 25 Legal Studies 499, R. Mullender, 'Negligence Law and Blame Culture: A Critical Response to a Possible Problem' (2006) 22 Professional Negligence 2, D. Lloyd, ‘The Compensation Culture: A New Legal Paternalism?’ in E. Lee (ed), Compensation Crazy: Do We Blame and Claim Too Much? (London: Hodder and Stoughton, 2002), F. Furedi, Courting Mistrust: The Hidden Growth of the Culture of Litigation in Britain (London: Centre for Policy Studies, 1999). 
generated for which ultimately we all must pay. ${ }^{3}$ This chapter examines the key factors which have contributed to what has become such a pejorative description of personal injury litigation. The analysis is divided into two parts: the total number of claims brought each year is discussed first, and this is followed by an assessment of the overall cost of disposing of individual actions. The chapter gathers together information from a variety of academic and practitioner sources to produce a novel and up to date perspective upon the compensation culture debate.

With regard to the first section the chapter shows that, although it is indeed true that claims have increased, they have done so only with regard to specific types of injury. What influences our different propensity to claim following one injury as opposed to another? Among the key factors highlighted are the working practices of three institutions which form the bedrock of our claims system: liability insurance companies, claims management organisations and claimant law firms. Criticisms are made here of a "dysfunctional" insurance industry; this is followed by a description of the rise and fall of an even more criticised claims gathering industry; and finally, attention is focused upon the rapidly changing structure of the legal profession involved in personal injury. All three of these institutions have had a profound effect upon the way that the compensation debate has developed.

When we turn to consider the rising cost of individual claims we ask to what extent are insurers and Health Authorities, among others, justified in their complaints that much more money now has to be paid out in damages and costs in order to dispose of each claim. The key changes to tort damages awards are summarised. Reforms have been made not only of the method by which compensation is calculated, but also of the form in which the money is to be paid: periodical payments are now common in

\footnotetext{
${ }^{3}$ However, among official investigations and reports the conclusion usually reached is that the fear of compensation culture is greater than that warranted by the evidence. See Better Regulation Task Force, Better Routes to Redress (Cabinet Office Publications, London, 2004), Government Response to the Better Regulation Task Force Report, Tackling the Compensation Culture (2004), Lord Young, Common Sense, Common Safety (Cabinet Office Publications, London, 2010), R.E. Löfstedt, Reclaiming Health and Safety for All: An Independent Review of Health and Safety Legislation (Department for Work and Pensions, 2011) Cm 8219. Despite limited evidence of the damaging effects of compensation culture, the Coalition Government has made significant reforms of the system. For the political background see Morris (2012) above $n 2$.
} 
cases involving serious injury. Damages for pain and suffering have been raised substantially without appreciating the full policy implications, whilst compensation for financial loss has had to be revised to match the realities of the wider financial world. These reforms are placed in a broader context which sees the increasing cost of claims as an inevitable result of closer adherence to the principle of restoring the claimant to the financial position that was enjoyed before the injury took place. Following proposals to reinforce that principle still further, one of the conclusions drawn in the final section is that the structural factors identified here will continue generate concern about "compensation culture" for some time to come.

\section{Compensation Culture Disease: The Dangers of New Diagnosis}

As the medical profession is aware, merely giving a name to an abnormal condition, whether physical or mental, can be a very significant event. It can help patients accept and come to terms with their illness. However, official recognition may also encourage doctors, patients and others to attribute symptoms too readily to the newly recognised condition. For example, it may be that children are prematurely labelled as suffering from attention deficit hyperactive disorder or dyslexia. The naming process makes some individuals too prepared to place the illness or disability into the new category. Examples especially relevant to personal injury litigation include whiplash injury and various states of mental upset, including post-traumatic stress disorder. ${ }^{4}$ Claimants may be presumed to be suffering from these conditions as a result of an accident without there always being sufficient foundation for this belief. Both the condition itself and the risk of developing it may have both been found too easily. This constitutes one of many "compensation culture" concerns.

If we examine the term "compensation culture" itself we can make a similar analysis. The phrase has a wide range of meanings. It has come to be used as a broad catch-all

\footnotetext{
${ }^{4}$ There is a marked difference in the practical importance of these two injuries. Whereas PTSD is a factor in less than 5,000 claims a year, whiplash accounts for about 480,000 claims and neck injury is a factor in $87 \%$ of all motor claims. See the Transport Committee, Eleventh Special Report, 2013-14, Cost of Motor Insurance: Whiplash: Further Government Response to the Committee's Fourth Report of Session 2013-14, (HC 902) 4 and Annex B. Despite its lesser importance, mental injury receives extensive discussion in tort textbooks whereas the effects of whiplash claims upon various aspects of the system are hardly considered.
} 
term to encompass a variety of concerns including many which are based upon misinformation about the litigation system and prejudice about lawyers. ${ }^{5}$ At its heart, as we shall see, there is indeed evidence which supports the need for careful monitoring of what actually happens in our tort system; there should especially be concern about certain features which have developed in recent years. However, the identification of potential and actual problems in that system has enabled all sorts of accusations to be levelled, many of them without empirical foundation. The ills have been too easily laid at the door of exploitative lawyers, fraudulent claimants or unscrupulous claims companies. One of those ills is that an increased burden has been placed upon society from the rising cost of personal injury litigation and this is the meaning associated with compensation culture that will be examined in the two parts which comprise this chapter.

\section{A. THE NUMBER OF CLAIMS}

\section{Trends in the Rate of Claiming}

A claim in tort is now made each year by about one person in every 64 in the UK. The total number of claims in 2015 is just short of a million, having exceeded that figure in the three years immediately preceding. As revealed in the table below which is derived from the official statistics, ${ }^{6}$ road and work accidents predominate. They loom

\footnotetext{
${ }^{5}$ W. Haltom and M. McCann, Distorting the Law: Politics, Media, and the Litigation Crisis (Chicago: University of Chicago Press, 2004), P. Almond, 'The Dangers of Hanging Baskets: “Regulatory Myths” and Media Representations of Health and Safety Regulations' (2009) 36 J Law \& Society 352 .

${ }^{6}$ In 1989 the Compensation Recovery Unit was set up by Government in order to recover from damages certain social security benefits that the claimant receives as a result of his injury. Reliable data has been generated on the number of claims, no matter whether successful or unsuccessful, and irrespective of whether the claim was settled or disposed of by a court hearing. See Department for Work and Pensions, Compensation Recovery Unit - Performance Statistics http://www.dwp.gov.uk/other-specialists/compensation-recovery-unit/performance-and-
} statistics/performance-statistics The reliability of the figures is discussed in R. Lewis, A. Morris and K. Oliphant (2006) above n 2. For more detail on the current figures see R. Lewis and A. Morris (2012) above $\mathrm{n} 2$. 
large over the practice of tort even though they constitute, at best, only about a half of all accidents. ${ }^{7}$

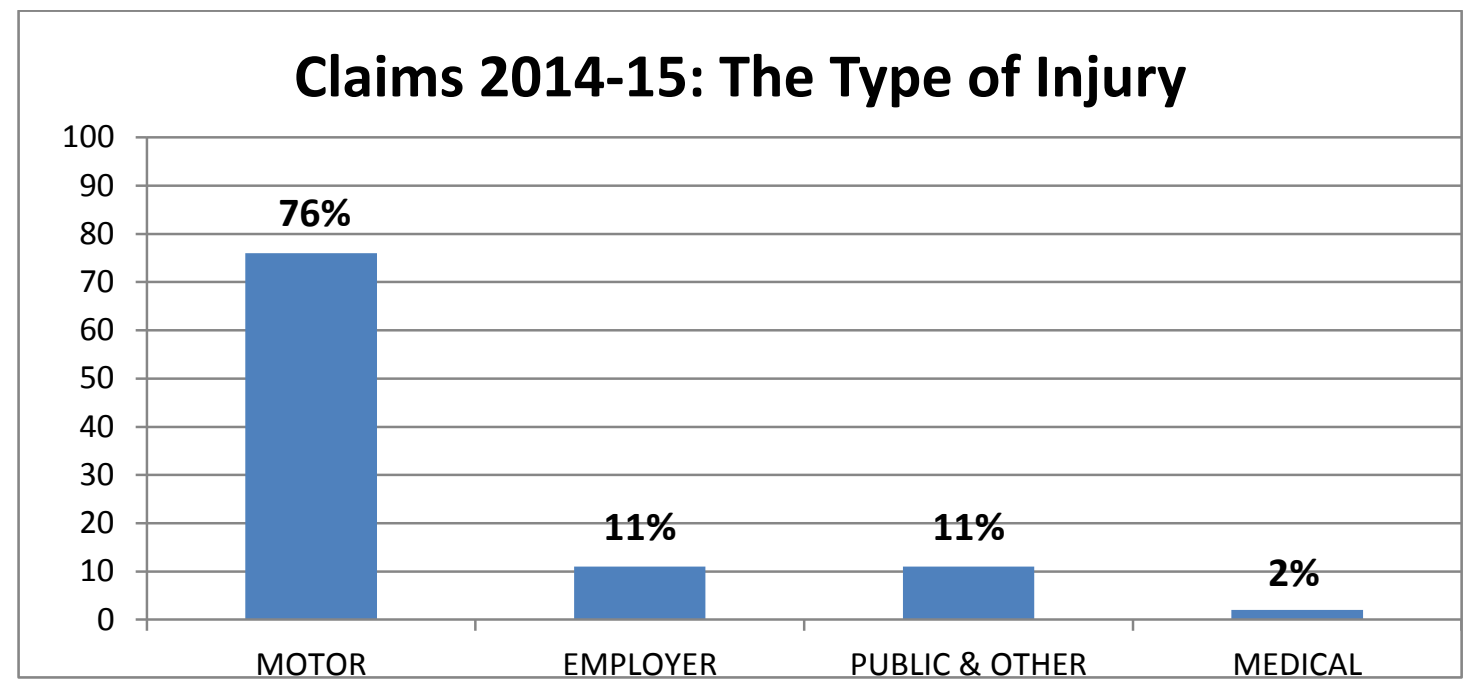

Whilst historical data are in short supply, those which are available support the view that over the long-term there has been a very substantial increase in claims. They appear to have risen four-fold since the 1970s. In 1973 the Pearson Commission estimated that there were about 250,000 claims. $^{8}$ In 1988 it was thought that claims had grown to around $340,000 .{ }^{9}$ This figure then doubled by the new millennium. Now claims are a third more than they were at the start of the millennium, the figure of a million being exceeded in 2012 and it has continued around that level since. ${ }^{10}$

${ }^{7}$ Report of the Royal Commission on Civil Liability and Compensation for Personal Injury (1978, cmnd 7054, chairman Lord Pearson) vol 2 table 57. In Australia road and work accidents are less than a fifth of the total. H. Luntz and D. Hambly, Torts: Cases and Commentary (Sydney: LexisNexis, $5^{\text {th }}$ edn 2002) 4 .

${ }^{8}$ Pearson Commission above n 6, vol 2 para 59.

${ }^{9}$ Lord Chancellor's Department, Report of the Review Body on Civil Justice (HMSO 1988, cm 394) para 391. This estimate is given with no indication of the facts upon which it is based and seems not to be derived from the research from Inbucon Management Consultants, Civil Justice Review: Study of Personal Injury Litigation (Lord Chancellor's Department, 1986).

${ }^{10}$ Compensation Recovery Unit figures, above n 6. For more detail see Lewis and Morris (2012) above n 2. 


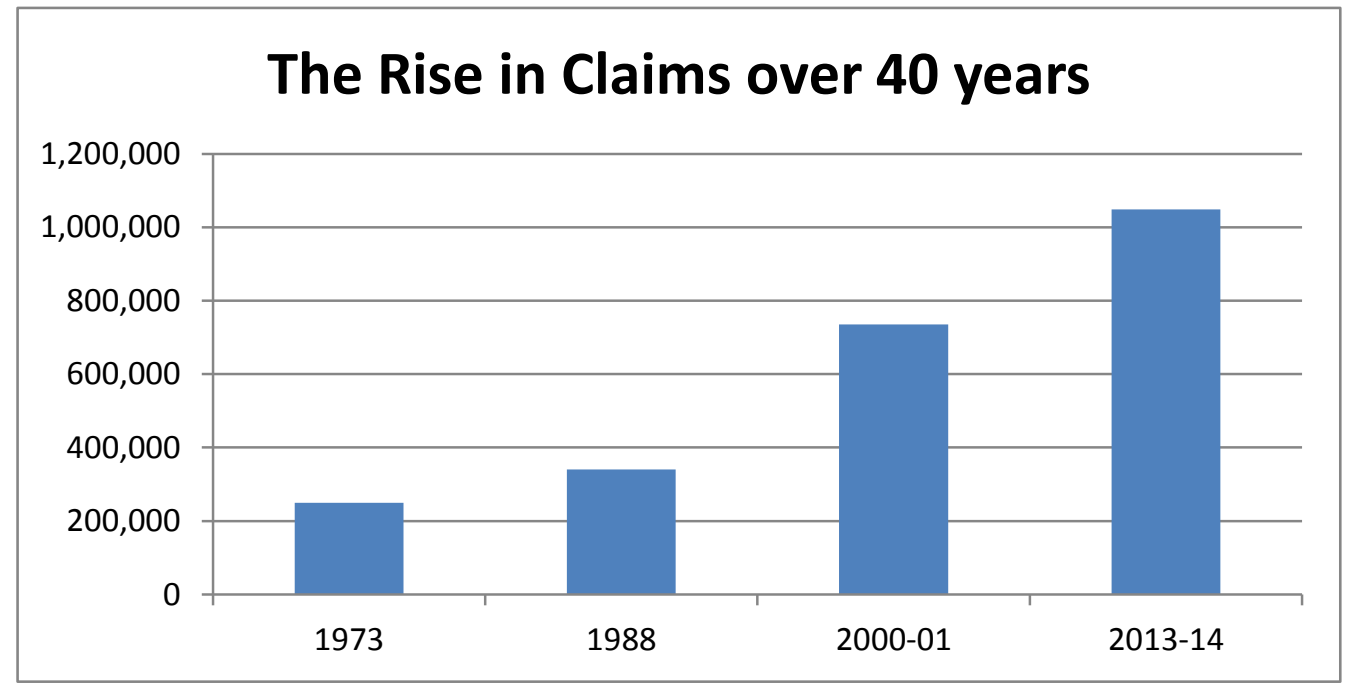

This rising trend in claims has not been a consistent one. Indeed the total number of claims actually fell slightly between 1998 and 2006 although it has risen in each year since. However, overall claims figures disguise major changes which have taken place in relation to particular kinds of injuries. These are revealed in the following table. ${ }^{11}$

\footnotetext{
${ }^{11}$ The table has been compiled by the author using the annual statistics published by the Compensation Recovery Unit, above $\mathrm{n} 6$.
} 


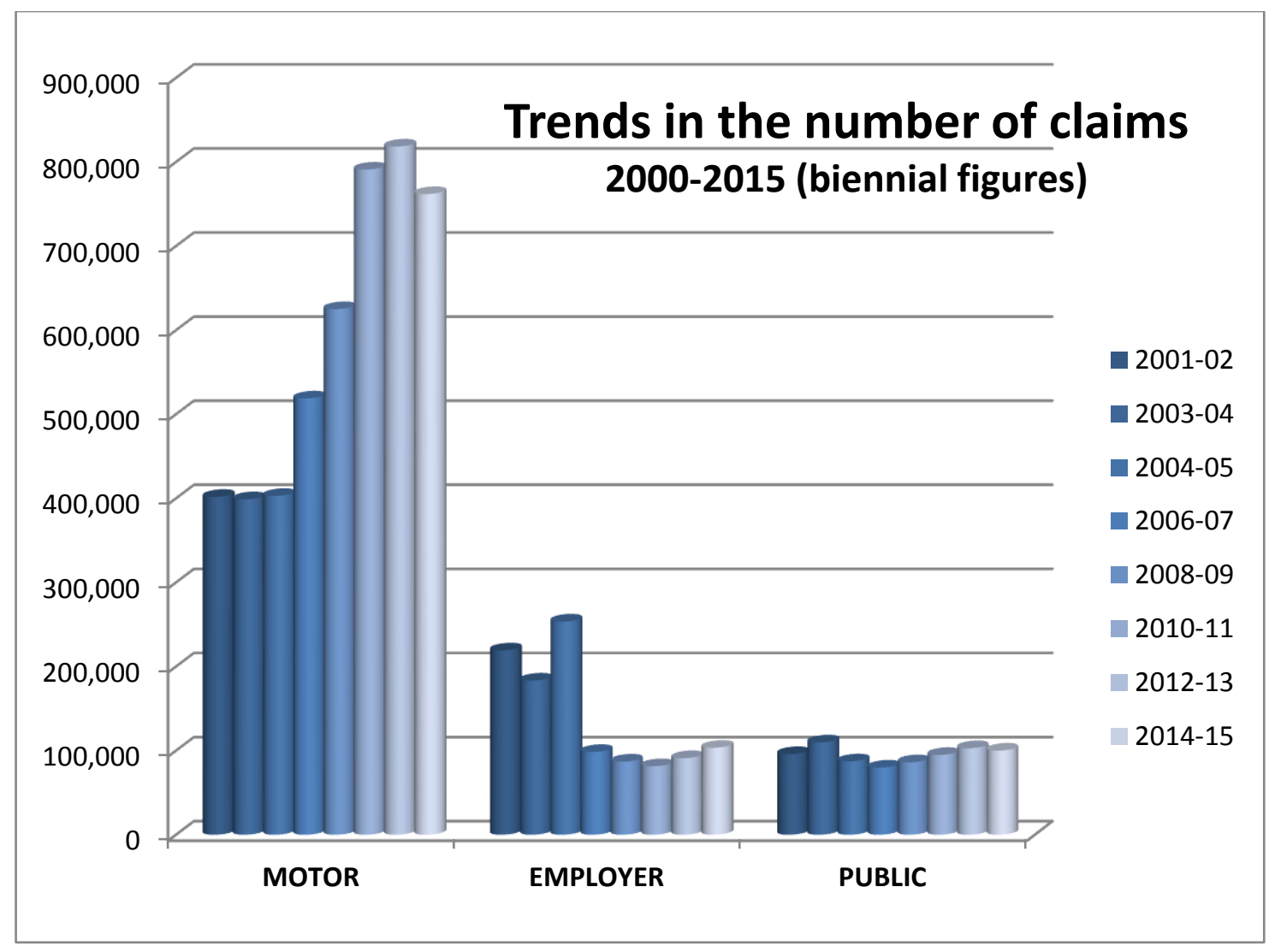

As can be seen, public liability claims in recent years have remained fairly constant, hovering around 100,000 a year. By contrast between 2000 and 2007 the number of employers' liability claims fluctuated considerably, reaching a peak of 291,000 in 2004. This was largely due to the creation of temporary special schemes of compensation for coalmining diseases. ${ }^{12}$ These schemes closed in 2004 and since then the annual number of employers' liability claims has fallen by almost two thirds to around 100,000. Although in the last four years claims have increased by a third, there are still fewer today than there were in 1973. They have declined in relative importance to such an extent that they now account for only 11 per cent of all claims whereas in 1973 they represented 45 per cent. ${ }^{13}$

\footnotetext{
12 The claims of miners in respect of, firstly, respiratory disease, and secondly, the use of vibrating tools led to settlement schemes which were called 'the biggest personal injury schemes in British legal history and possibly the world.' From 1999-2004 about 760,000 claims were registered. Department of Trade and Industry, Coal Health Claims http://www.dti.gov.uk/coalhealth/01.htm

${ }^{13}$ Only one in seven workers suffering disease or injury make a claim according to the Trades Union Council and the Association of Personal Injury Lawyers, The Compensation Myth: Seven Myths about the "Compensation Culture" (2014).
} 
In stark contrast to the other types of claim, there has been both a long-term and shortterm increase in the number of road traffic accident (RTA) claims involving personal injury. Between 2000 and 2004 such claims actually fell but since 2004 there has been an increase every year except for the last two with the result that the total over the last ten years has doubled to 761,000 . This increase is largely responsible for the longterm rise in the total of all personal injury claims. In 1973 RTAs constituted $41 \%$ of all personal injury claims. By 2001 this had increased to 54\% and by 2014 RTAs constituted $76 \%$ of all claims. A notable feature has been the growth of claims involving whiplash injuries which now constitute well over half of all claims made. ${ }^{14}$ Supposedly, by 2004 the UK had substantially more whiplash cases than any other European country and since then the number of claims has doubled. ${ }^{15}$

This rapid expansion in the overall number of claims can be explained by a combination of factors that relate, firstly, to the institutions which play a leading part in personal injury practice, and secondly, to the individual that makes the claim. The following account does not seek to deal with these factors in detail, but does highlight some of the more recent developments.

\section{Institutional and Personal Factors Encouraging Claims}

Our propensity to claim is very much affected by the institutions involved in personal injury practice. A major example is the role that trade unions have played in

\footnotetext{
${ }^{14}$ There were 480,000 whiplash claims in 2012-13 constituting 58\% of all motor personal injury claims. However, the increase in motor personal injury claims has also been driven by claims with a description of 'neck or back' injuries. Over the last five years, these claims have almost trebled to around 270,000. Claims which would have previously been labelled as 'whiplash' are now instead being labelled as 'back or neck' injuries. This means that neck injuries which include whiplash account for $87 \%$ of all road traffic claims. Transport Committee, Eleventh Special Report, 2013-14, Cost of Motor Insurance: Whiplash: Further Government Response to the Committee's Fourth Report of Session 2013-14, (HC 902) 4.

${ }^{15}$ European Insurance and Reinsurance Federation (CEA), Minor Cervical Trauma Claims (2004) 4. In its response to the Ministry of Justice Consultation CP17/2012 APIL emphasised the European data is unreliable and outdated, and in its response the Law Society similarly doubts the insurers' figures. For more detail see the chapter in this book by Ken Oliphant, 'The Whiplash Capital of Europe? European Perspectives on Compensation Culture.'
} 
encouraging and facilitating claims for work accidents and diseases. ${ }^{16}$ Following injury, members have been able to gain access to union counselling and free legal advice. The organised referral of these assisted claims to particular law firms led to the first specialised personal injury representation for injured claimants. This made a considerable difference to whether a claim was brought and for how much it was settled; the reputation of certain trade union lawyers as hard negotiators and aggressive litigators continues to this day. However, union membership has declined from a peak of about 13 million in 1979 to half of that figure today. ${ }^{17}$ This still means that about a quarter of the workforce is covered, although there is a much greater concentration in public as opposed to private employment where there is only 14 per cent membership. Apart from trade unions, in recent years three other institutions have significantly affected our propensity to claim damages: liability insurers, claims management companies and claimant law firms.

\section{Liability Insurers}

A fact which has always been well known to practitioners has begun to attract more attention from academics recently: it is increasingly appreciated that insurance companies are fundamental to tort and the operation of the personal injury system. ${ }^{18}$ They are its "lifeblood." What they do very much affects whether a claim is made, how it is processed and the amount of damages paid. Liability insurance is not merely an ancillary device to protect the insured, but is the "primary medium for the payment of compensation, and tort law [is] a subsidiary part of the process.",19

Although the great majority of claims are brought against defendants who are individual people, they almost all are insured. In nine out of ten cases the real

\footnotetext{
${ }^{16}$ G. Latta and R. Lewis, 'Trade Union Legal Services' (1974) 12 British J Industrial Relations 56. For an engaging account of the emergence of the former leading trade union law firm see $S$. Allen, Thompsons: A Personal History of the Firm and its Founder (Merlin Press, 2012).

${ }^{17}$ Department for Business, Innovation and Skills, Trade Union Membership 2013: Statistical Bulletin.

${ }^{18}$ R. Merkin and J. Steele, Insurance and the Law of Obligations (Oxford: OUP, 2013), R. Lewis, 'Insurance and the Tort System' (2005) 25 Legal Studies 85, R. Lewis, 'Insurers and Personal Injury Litigation: Acknowledging "The Elephant in the Living Room"” [2005] JPIL 1, J. Morgan, "Tort, Insurance and Incoherence' (2004) 67 Modern Law Rev 384 and G. Wagner (ed), Tort Law and Liability Insurance (New York and Vienna: Springer Publishers, 2005).

${ }^{19}$ P. Cane, Atiyah's Accidents, Compensation and the Law (Cambridge: CUP, $6{ }^{\text {th }}$ ed 1999) 191.
} 
defendants are insurance companies, with the remainder comprising large self-insured organisations or public bodies such as local authorities. ${ }^{20} \mathrm{~A}$ handful of insurers dominate the market so that in motor claims four companies only are responsible for over half the premiums collected, these being Direct Line, Admiral, Aviva and AXA ${ }^{21}$ Insurers are the real paymasters for the tort system for they are responsible for $94 \%$ of the compensation paid out for personal injury. ${ }^{22}$ They fund not only the damages award itself but also most of the administrative and legal costs of the system. They provide legal representation not only for most defendants but also many claimants. The reason for this lies in the rapid expansion in recent years of before-theevent (BTE) insurance. This form of legal expenses insurance covers almost 3 in 5 adults. $^{23}$

The influence of insurers inevitably permeates the system. Intuitively we might expect that out of self-interest insurers would act as the system's gatekeepers and policemen. This might involve them discouraging certain claims being made in the first place, carefully examining those that are brought and paying up only when evidence of legal liability is clear. However, the reality has been far from this. In recent years insurers have actually encouraged claims in a number of ways and they have very readily made payments, albeit usually of low amounts.

An insurer's desire to defend a case has always had to be tempered by cost considerations. A heroic defence denying that a driver has been negligent in a marginal case may prove not only to be a risky but also a very expensive tactic. This is especially the case where the damages claimed are small. Legal costs then can

\footnotetext{
${ }^{20}$ Even where local authorities fund damages awards directly, they may still employ private insurance company personnel to handle the claims made against them. S. Halliday, J. Ilan and C. Scott, 'StreetLevel Tort Law: The Bureaucratic Justice of Liability Decision-Making' (2012) 75 Modern Law Rev 347 at 356.

${ }^{21}$ This is based on market share in 2012. See the evidence of Thompsons solicitors to House of Commons Transport Committee, Driving Premiums Down: Fraud and the Cost of Motor Insurance (2014) First Report of Session 2014-15 (HC 285).

${ }^{22}$ Pearson Commission above n 7, vol 2 para 509.

${ }^{23}$ R. Lewis, 'Litigation Costs and Before-The-Event Insurance: The Key to Access to Justice?' (2011) 74 Modern Law Rev 272, FWD Group, The Market for 'BTE' Legal Expenses Insurance (2007) para 3.3 .
} 
easily exceed the sum being claimed. ${ }^{24}$ This danger is present in the majority of cases because the average payment of damages is less than $£ 5,000 .^{25}$ As a result, it is unusual for insurers to contest liability: one study of insurers' files revealed that they 'contained remarkably little discussion of liability,' finding it initially denied in only $20 \%$ of cases. ${ }^{26}$ In fact claimants succeed in more than 9 out of 10 cases. ${ }^{27}$ Because insurers make some payment in this great majority of cases, in effect, they encourage claims to be made.

Insurers also encourage claims by giving claimants ready access to a lawyer: they provide legal expenses insurance as an extra benefit in the motor and home policies they sell. Not only do insurers profit from this by including an additional cost in the premiums charged, but they also used to receive a referral fee from solicitors for each personal injury case they forwarded to their associated law firm. Referrals earned

\footnotetext{
${ }^{24}$ Lord Justice Jackson found evidence of disproportionately high costs in his Review of Civil
} Litigation Costs: Final Report (January 2010). Data collected for one survey showed that for 280 cases which had come before the District Court the claimant costs alone amounted to $£ 1-80$ p for every $£ 1$ of damages paid. On average, costs exceeded damages for cases settled up to $£ 15,000$ in the 'fast track' procedure. Previously insurers had stated that overall they paid an additional $38 \mathrm{p}$ in legal costs for every $£ 1$ recovered by the claimant but that this rose to $90 \mathrm{p}$ for claims below $£ 5,000$. See The $A B I$ Response to the Government's Consultation on Case Track Limits and the Claims Process for Personal Injury (2007).

${ }^{25}$ In a survey of conditional fee claimants in 2011 half of them received less than $£ 5,000$. Insight Delivery Consultancy, No Win No Fee Usage in the UK appendix 5 of the Access to Justice Action Group, Comments on Reforming Civil Litigation Funding http://www.accesstojusticeactiongroup.co.uk/home/wp-content/uploads/2011/05/NWNF-research.pdf P. Fenn and N. Rickman, Costs of Low Value Liability Claims 1997-2002 record average damages of only $£ 3,000$ for employers’ liability accident claims.

${ }^{26}$ T. Goriely, R. Moorhead and P. Abrams, More Civil Justice? The Impact of the Woolf Reforms on Pre-Action Behaviour (2002) 103.

${ }^{27}$ As a rough estimate, based on Compensation Recovery Unit figures, above $\mathrm{n} 6$, the average ratio of RTA settlements to claims made for the last six years is $90 \%$. There is a time lag between claims and settlements which, given the steep recent rise in claims, makes the actual success rate somewhat higher than 9 out of 10 despite the suspected growth of unmeritorious actions which are likely to be unsuccessful. 
insurers about $£ 700$ per case $\mathrm{e}^{28}$ and constituted a substantial income. For example, Admiral insurance company received over $£ 18$ million in referrals in 2012. This was about $£ 6$ for each vehicle it insured and constituted $6 \%$ of its profit. ${ }^{29}$ A related practice of insurers was to collect information about all potential claimants in an accident and again sell those details to law firms. The result was the development of an ultimately flawed business practice: profit was sought from these individual cases but in doing so a more febrile claims atmosphere resulted. Both insurers and premium payers at large eventually suffered. ${ }^{30}$

Gradually insurers became increasingly concerned about the problems which they had in part created. These included not only the rising number of claims but also the increasing legal costs to which they became subject. Legal aid for personal injury was largely abolished in 2000 and this stimulated the widespread use of conditional fee agreements. ${ }^{31}$ Under these agreements claimant lawyers could secure an increase in their fees in each case that they won. They could recover up to double their costs if successful. In seeking to avoid or reduce these costs insurers adopted practices which again in the longer term had the opposite effect of that originally intended. For example, one tactic still used today is "third party capture." This is where the insurer makes a direct approach to any injured party who is not their own insured. They may do so either before or after they have contacted a solicitor. Insurers seek a quick settlement of the potential claim before any legal costs can be incurred. This has resulted in many people with only very minor injury from the accident in which they were involved (or often no injury at all) being offered sums to settle cases which they had no previous intention of bringing! Claimants' solicitors have been especially

\footnotetext{
${ }^{28}$ Otterburn Legal Consulting, Personal Injury Marketing and Referral Fees, Report for the Association of Personal Injury Lawyers (2012). R. Jackson LJ, Review of Civil Litigation Costs: Final Report (London: Judiciary of England and Wales, January 2010) 202.

${ }^{29}$ Admiral Annual Accounts 2013. J. Hyde, ‘Admiral still cashing in on PI referral fees' [2013] Law Society Gazette, 4 March. It had long been recognised that referral fees constituted a major part of the profits from providing BTE. See FWD, The Market for 'BTE' Insurance (Ministry of Justice, 2007) at 4A II 4.

${ }^{30}$ J. Straw, 'Dirty secret that drives up motor insurance; Companies are selling drivers' details to claims firms exploiting no-win no-fee system' The Times, 27 June 2011.

${ }^{31}$ The Access to Justice Act 1999 s 27 and s 29.
} 
upset by a small minority of insurers who have approached their clients directly even after they have engaged legal help. A test case against one insurer alleging that claimants have been induced to break their contracts with their solicitors could mean that hundreds of settlements which have been agreed since 2009 will be reopened. ${ }^{32}$ A similar insurer tactic employed to reduce legal costs which has also had the unintended effect of encouraging claims has been for insurers to make "pre-med offers." These are offers made to the claimants' solicitors very early in the proceedings, often immediately on receiving notice of a claim, and before any medical report has been obtained. They are pitched at a low level, usually less than $£ 1,500$, and are aimed at removing the nuisance value of a small claim together with its potentially disproportionate legal and disbursement costs. For example, until recently a quick offer could save an insurer paying up to $£ 700$ (now reduced to a maximum of $£ 180$ ) for the cost of a medical report even though these are often standard form and can be produced by a mere GP. ${ }^{33}$ Commonly made in whiplash cases, these pre-med offers have been heavily criticised on the one hand as attempts to buy off claims for derisory amounts ${ }^{34}$ and, on the other hand, as encouraging claims where injury is non-existent and thus feeding the compensation culture. ${ }^{35}$ There have been proposals that a medical examination and report should be made compulsory before settlement. ${ }^{36}$ Although the Ministry of Justice wants to discourage pre-med offers it has opted against making such a ban. ${ }^{37}$

\footnotetext{
${ }^{32}$ Gavin Edmondson Solicitors v Haven Insurance [2014] EWHC 3062 QB is to be appealed. See 'Insurer in line of fire over client capture’ [2014] Law Society Gazette, 17 November.

${ }^{33}$ https://www.gov.uk/government/news/fee-cut-for-whiplash-medical-reports

${ }^{34}$ For example, J. Spencer, 'Pre-med offers result in injustices' [2014] Law Society Gazette, 11 March, and S. Rigby, (2014) 158 (7) Sol J 15.

${ }^{35}$ Ministry of Justice, Reducing the Number and Cost of Whiplash Claims: A Government Response to Consultation (October, 2013) $\mathrm{cm} 8738$.

${ }^{36}$ See the recommendation in the House of Commons Transport Committee, The Cost of Motor Insurance: Whiplash, Fourth Report of Session 2013-14 (HC 117) and the especially the evidence of the Motor Accidents Solicitors Society. The Association of Personal Injury Lawyers has similarly opposed such offers.

${ }^{37}$ Above n 32.
} 
Criticism of insurers making very ready offers was voiced by a solicitor interviewed as part of the author's forthcoming contribution to an empirical project investigating personal injury practice in several European countries and funded by the European Centre of Tort and Insurance Law. He said:

"... if it becomes known, as I think it did with whiplash, that all you have to do is say: 'I was in a car accident' and really the insurers just pay you some money, I'm not sure that's necessarily a good message to be sending out to the public. I think that insurers have got caught ....If they're going to make those sort of offers, they can expect people just to have a go all the time."

The conclusion of a Parliamentary committee was that "a highly dysfunctional market" has been created "in which the pursuit of profit by the different firms involved has led to higher prices for consumers and, in some cases, business practices which are not in the consumer interest." ${ }^{38}$ Overall it is clear that certain routine institutional practices of insurers in processing claims have significantly contributed to some of the problems now identified as part of compensation culture.

\section{Claims Management Companies}

Claims management companies (CMCs) first emerged about twenty years ago. They made money by trawling for accident victims and seeking quick settlements from which they extracted high fees from claimants. Alternatively, they passed on their clients to solicitors and received a referral fee in return. Today they also offer services such as vehicle repair and credit hire, and some can arrange accident reports and evidence from medical experts. To recruit clients, CMCs have used a variety of tactics from mass media advertising to direct approaches to individuals in the street. ${ }^{39}$ Over three-quarters of the population have reported being contacted about making a claim. $^{40}$

The growth of CMCs was fuelled especially by the removal of legal aid in 2000 which led to the more extensive use of conditional fee agreements. Under these agreements claimant lawyers could secure an increase in their fees in each case that

\footnotetext{
${ }^{38}$ The House of Commons Transport Committee (HC 285) above n 20, para 38.

${ }^{39}$ National Association of Citizens Advice Bureaux, Door to Door: CAB Clients' Experiences of Doorstep Selling (2002).

${ }^{40}$ ABI, News Release 29/12, 19 June 2012.
} 
they won. They could recover up to double their costs if successful but nothing at all if they lost. This potential for increased profit added to the incentives to obtain referrals. One problem solicitors faced was that conduct rules prevented them from paying CMCs for these claims. However, these rules were flouted on such a regular basis that the ban on referral payments was eventually lifted in $2004 .^{41}$ The development of an efficient, high volume claims department founded upon referrals and advertising proved to be a successful business strategy for a number of law firms. However, there was growing concern about the abuses that resulted from CMCs being given such a free rein. The press, in particular, used CMC "to describe anything and anyone who is perceived as promoting 'compensation culture,' ripping off consumers, stealing from them and ultimately 'mugging' the most vulnerable in our society." 42 There continues to be foundation for such stories: only recently CMCs have been found guilty of a range of misdemeanours from helping to arrange 'crash-for-cash' scams to bribing policemen to steal details of accident victims from a police computer. ${ }^{43}$ To combat some of the more extreme practices, the Government began to regulate the operation of CMCs in $2007 .{ }^{44}$ In response to attempts to prevent them making approaches in person, the companies adapted by sending unsolicited text messages and making unsolicited phone calls. ${ }^{45}$ Although these practices were later banned, other tactics continued to prove successful as evidenced by the fact that the largest increases in claims are found in areas where CMCs are concentrated. ${ }^{46} \mathrm{By}$ 2010 the turnover of CMCs from personal injury work was almost a fifth of that of

\footnotetext{
${ }^{41}$ A. Higgins, 'Referral Fees - The Business of Access to Justice' (2012) 32 Legal Studies 109.

${ }^{42}$ A. Wigmore, 'The Death of Claims Management Companies' [2013] JPIL 248.

${ }^{43}$ Ministry of Justice, Enforcement Actions Carried Out by CMR, (The Stationery Office, June 2014).

${ }^{44}$ The Compensation Act 2006 s 4 and the Compensation (Claims Management Services) Regulations 2006 (SI No 3322).

${ }^{45}$ M. Boleat, (2010), Ministry of Justice, Claims Management Regulation Annual Report 2010/2011

(2011). Despite later being banned, unsolicited approaches continue. In 2014 the Information Commissioner's Office reported that 2,355 complaints concerning calls or texts concerning accidents were made for the month of November alone. J. Hyde, ' PI Nuisance Calls still Plaguing Consumers' [2014] Law Society Gazette, 14 December.

${ }^{46}$ Especially Manchester, Liverpool and Birmingham. D. Brown and S. MacDonnell, Update from the Third Party and PPO Working Parties (Faculty of Actuaries, 2012). 'Liverpool is whiplash capital of Britain' [2012] Financial Times, May 27.
} 
solicitors' firms. ${ }^{47}$ The number of CMCs continued to grow, reaching a peak in late 2011 when there were 2,553 companies operating in the personal injury claims sector. However, following increased regulation and, in particular, the banning of referral fees in $2013^{48}$ they have been halved in number to around 1,125. This resulted in a similar reduction in their turnover which fell from $£ 455 \mathrm{~m}$ to $£ 238 \mathrm{~m}$. ${ }^{49}$

As discussed under the next heading, this decline in CMCs does not necessarily indicate a commensurate reduction in marketing and the aggressive pursuit of potential claimants. At the same time that referral fees were banned, claimant law firms also found that they were no longer able to recover their success fee from insurers. ${ }^{50}$ These two changes are having a major effect upon the structure of personal injury law firms and the business models they now adopt. It is to these changes that we now turn.

\section{Claimant Personal Injury Law Firms}

Initially solicitors' firms were very reluctant to become involved with what was considered the distasteful business of claims gathering. By the late 1990s, however, following the relaxation of the rules on advertising, specialist personal injury firms were actively seeking clients. ${ }^{51}$ They still avoided the brash techniques of CMCs but many were prepared to pay referral fees to these companies; they were content to "turn a blind eye" in order to secure a regular flow of work. ${ }^{52}$ Eventually more law firms recognised that the work being done by CMCs could be replicated by them. A

\footnotetext{
${ }^{47}$ It amounted to $£ 377$ million compared to about $£ 2$ billion received by solicitors. London Economics, Access to Justice: Learning from Long Term Experiences in the Personal Injury Legal Services Market (Report for the Legal Services Board) (2014) 4 and 59.

${ }^{48}$ The Legal Aid, Sentencing and Punishment of Offenders Act 2012 s. 56 prevents the payment of referral fees. However, the Claims Management Regulator has continued to issue warnings about the companies failing to comply.

${ }^{49}$ As at March 2014. Ministry of Justice, Claims Management Regulation: Annual Report 2013-14.

${ }^{50}$ The Legal Aid, Sentencing and Punishment of Offenders Act 2012 s. 44 makes claimants liable to pay the uplift in fees out of their damages.

${ }^{51}$ R. Abel, English Lawyers between Market and State: The Politics of Professionalism (New York: OUP, 2003) and H. Kritzer, 'The Fracturing Legal Profession: The Case of Plaintiffs' Personal Injury Lawyers' (2001) 8 International Journal of the Legal Profession 225.

${ }^{52}$ For more details see A. Wigmore, above n 42.
} 
few firms even adopted certain tactics which matched some of the excesses of the CMCs. For example, some offered inducements to sue including free iPads, shopping vouchers or cash promises of up to $£ 2,000 .{ }^{53} \mathrm{CMCs}$ were banned from making such gifts but solicitors continued to be able to do so until $2015 .{ }^{54}$ Although only a minority offered such inducements, the aggressive claims gathering of the profession has now resulted in solicitors supplanting many CMCs. According to the policy director of the Claims Standards Council:

"In 2013, over 90 per cent of law firms now practice what they used to criticise. They market and advertise very efficiently spending over $£ 60$ million a year, which is double the spend of two years ago. They have marginalised the traditional CMC to such an extent that less than 70,000 claims from a total of 600,000 claims are generated by traditional CMC activity. That figure will decline and so will CMCs." 55

Further changes have occurred following the relaxation of the rules relating to the ability of law firms to form business relationships with other enterprises. Since 2011 non-lawyers have been able to own and manage legal practices as part of an 'alternative business structure' (ABS) which can involve a multi-disciplinary partnership. Over 240 licences for such arrangements have been granted by the Solicitors Regulation Authority in the last two years. The ABS is a particularly attractive vehicle for conducting personal injury work. The wider organisation can include within it, for example, a medical reporting agency that is able to give evidence on claims, or a financial department that gives advice on how a damages award should be invested. For present purposes, however, the significant advantage of an $\mathrm{ABS}$ is that it enables personal injury firms to avoid the difficulties caused by the prohibition of referral fees by making such payments 'in house.' As a result we have seen leading personal injury firms merge with CMCs or insurance companies. For example, Admiral Insurance has taken over the legal firms of Lyons Davidson and

\footnotetext{
${ }^{53}$ C. Budsworth, 'Should solicitors be able to offer financial inducements to claimants?' (2014) 158

(17) Sol J.

${ }^{54}$ Inducements to claim were banned by the Criminal Justice and Courts Act $2015 \mathrm{~s} 58$. This measure was strongly supported by House of Commons Transport Committee (HC 285) above n 21.

${ }^{55}$ A. Wigmore, above n 42.
} 
Cordner Lewis whilst Ageas insurance is now in partnership with New Law

Solicitors. Similarly, trade unions have also entered into associations with law firms. ${ }^{56}$

The growth of ABS practices has been dramatic. Perhaps the best example involves the prominent trade union linked firm of Russell, Jones and Walker which acquired the notorious CMC, Claims Direct, only for it then to be merged with the very large international ABS firm of Slater \& Gordon. This took place in 2012 and was the first U.K. acquisition of that ABS firm, which originates from and has its shares listed in Australia. Attracting some controversy, the firm is the only one in the world to be publicly listed on the stock exchange and to derive its capital base from shareholders in this way. Slater \& Gordon has aggressively expanded in this country since making its first acquisition here two years ago. Its share price and profits have risen sharply following its take-over of other key claimant firms such as Fentons and Pannone. It now has almost two thousand U.K. employees spread around eighteen locations. ABS firms accounted for a fifth of the turnover of personal injury solicitors' firms in 2012 13. That figure will rise sharply as more alternative practices are established. Their expansion continues apace, especially that of the Slater \& Gordon whose turnover doubled in the last financial year to over $£ 100$ million, with over 80 per cent of its total revenue being derived from personal injury work ${ }^{57}$

To secure economies of scale there have also been a series of mergers of traditional personal injury firms outside of the ABS umbrella. Mergers of whatever kind have been accompanied by a drive for efficiency in order to deal with the mass of small

\footnotetext{
${ }^{56}$ Morrish has formed an association with the Transport Salaried Staffs' Association. Thompsons, the best known trade union firm, became an ABS in 2012 but its refusal to enter into an arrangement with the GMB trade union resulted in it being dropped from its panel of solicitors in 2014. J. Hyde, 'Trade union to partner law firm' [2013] Law Society Gazette, 23 December.

${ }^{57}$ Slater \& Gordon's turnover in the U.K. increased by $119 \%$ during the 2013-14 financial year. [2014] The Lawyer, 25 September. Its acquisition of the Cardiff based firm of Leo Abse in 2015 was its seventh in just over a year. It then made its most significant acquisition to date by acquiring a division of Quindell for $£ 677$ million, more than doubling the 2000 staff it employs. It thus raised its share of the U.K. personal injury market to $12 \%$, twice that of its nearest competitor, Irwin Mitchell. According to their managing director, the deal allowed it "to penetrate the highly fragmented $£ 2.5$ billion UK personal injury market." For its rationale in securing finance by publicly offering shares see A. Grech and K. Morrison, 'Slater \& Gordon: The Listing Experience' (2009) 22 Georgetown J Legal Ethics 535 .
} 
claims which dominate the system. Largely because of funding constraints, much of the work involving smaller run-of-the-mill claims in these firms is now being carried out by unqualified or paralegal personnel. ${ }^{58}$ They are working in what has been identified in the USA as "settlement mills" where the assembly line resolution of claims "represents quite a departure from the intimate, individualized, and factintensive process thought to underlie the traditional process of tort." ${ }^{, 59}$ The legal process has been de-skilled and de-personalised in these factories which have direct comparators in the U.K.

The funding reforms and new business opportunities have convinced a former President of the Association of Personal Injury Lawyers that firms must now "get big, get niche or get out." ${ }^{, 60}$ In other words, they need to either become larger and more efficient or develop specialist skills in order to deal with the minority of claims where more serious injury is suffered. Otherwise they will fail. These views are echoed by the head of Slater \& Gordon who predicts that in the near future just three firms will control up to $40 \%$ of personal injury claims. ${ }^{61}$ Some may think this a dramatic claim, but there have been more firms closing their doors than ever before and 'run off' insurance is now a favoured topic for professional development seminars. In 2013 a book was published giving advice on developing a personal injury practice for the future under the more limited costs regime. A year later the author's law firm went into administration. ${ }^{62}$

\footnotetext{
${ }^{58}$ Association of Personal Injury Lawyers, The Impact of the Jackson Reforms on Costs and Case Management (Evidence to the Civil Justice Council) (2014). D. Evans, 'Shifting Strategy in the Personal Injury Market' [2014] JPIL 85.

${ }^{59}$ N. Engstrom, 'Sunlight and Settlement Mills' (2011) 86 New York University LR 805 at 810 and by the same author, 'Run-of-the-mill Justice' (2009) 22 Georgetown J of Legal Ethics 1485.

${ }^{60}$ David Marshall (2013) 157 Sol J October 16.

61 'Slater chief predicts rapid consolidation in PI market' [2014] Law Society Gazette, 1 May. A year later, the three leading firms controlled an estimated 22 per cent of the market. N. Rose, 'Slater \& Gordon strikes $£ 677$ million deal to buy Quindell’s professional services division’ Legal Futures, 30 March 2015.

62 ‘Surviving Jackson author closes firm’ [2014] Law Society Gazette, 15 December. J. Zindani and D. Regan, Surviving Jackson - Developing a Personal Injury Practice for the Future (Sun Legal Publishing, 2013).
} 
All this cost-cutting and consolidation in the market is matched by the continued aggressive searching for potential clients and the further encouragement of claims in tort, albeit in a regime which now has reduced funding because of the loss of the ability to reclaim success fees and insurance premiums. It is a time of very rapid change. The focus of attention has been upon how claims are funded and what rules of civil procedure should apply. However, it is perhaps even more important to appreciate the changes that are taking place in the structure of the legal profession and the personnel now involved in personal injury litigation. The reforms are thus having a considerable effect upon how tort actually operates in practice; they will help determine how compensation culture is perceived in the future.

\section{Personal Factors Encouraging Claims}

Apart from these institutional influences, there are factors which are personal to the individual claimant which can account for the increase in claims. These are not discussed in detail here partly because the analysis of "naming, blaming and claiming" is well known. ${ }^{63}$ That is, the individual first has to recognise that he has suffered an injury; then he needs to attribute responsibility; and only finally does he seek formal recompense for his loss. ${ }^{64}$ The increase in claims is the result of a complex mix of changing personal factors which affect all three parts of this analysis. It is certainly the case that we are less prepared to put up with misfortune than in the past. Today we are more likely to recognise that we have suffered from wrongdoing. We are better able to identify, for example, the work-related factors that are the cause of our injury or disease, and we are also are more willing to sue our employer. To an extent this may be because we have less fear of recrimination although many workers are still concerned about discrimination after being labelled an "awkward" employee. The seriousness of the injury is also a major factor in determining whether a claim is made for it is clear that it is much more likely that recompense will be sought if substantial financial loss is suffered.

\footnotetext{
${ }^{63}$ W. Felstiner, R. Abel and A. Sarat, 'The Emergence and Transformation of Disputes: Naming, Blaming and Claiming' (1981) 15 Law \& Society Rev 631.

${ }^{64}$ See Morris (2007) above $\mathrm{n} 2$ at 372 et seq.
} 
This last fact may make it appear that tort compensation follows where the need is greatest. However, in fact the reverse is true. This is because the vast majority of claims brought today are for relatively minor road traffic injuries which have little effect on the pocket and no long-lasting consequences. The increase in these types of claims reflects a significant change in social mores. Even though the injury is minor, we have been encouraged to seek compensation as if it were a consumer right. Artful advertising can make lawyers appear not just accessible but even friendly and their hourly charges do not hold the fears they once did. The claim appears risk-free, stressfree and involving merely an administrative process. It is legitimised by the routine, de-personalised and non-adversarial nature of the mass of litigation for minor injury. The message is that you hardly need to get directly involved and that you will certainly not end up in court; your claim will be dealt with as merely a private transactional exercise arranged between anonymous bureaucratic organisations.

When the individual weighs up the pros and cons of claiming a major element will be the risk of incurring legal costs against the level of potential reward. The fear of being out of pocket should the claim fail has been largely removed by the "no-win, no fee" mantra supplemented by the availability of insurance against potential liability to pay the defendant's costs. The possibility of getting nothing from the process seems remote. The utility of claiming therefore seems high. This is accentuated by the increasing levels of damages on offer. This brings us to consider the second part of this chapter which focuses upon the rising cost of individual claims.

\section{B. THE RISING COST OF CLAIMS}

\section{The Changing Form of Payment: Periodical Payment Orders}

A significant cause of the increased cost of claims has been the change made in the way in which damages may now be paid: periodical payments have replaced lump sums in many cases where serious injury is involved. The lump sum system survived almost intact until about twenty five years ago. Damages almost always took the form of one large payment made on a once and for all basis. However, that system imposed upon claimants an enormous responsibility for their future: they had to manage the lump sum in order to ensure that it would continue to meet their needs for the rest of their life. Unfortunately, inflation and the vagaries of the returns upon investment 
often resulted in the rapid erosion of the compensation. In addition, the damages were bound to be insufficient where losses continued for a longer period of time than that forecast in the settlement or in the court judgement. This frequently happened where the compensation depended upon an assessment of life expectancy for then the money was bound to run out if the claimant lived longer than forecast. Recipients of damages awards thus not only had the risk of investment thrust upon them but also the risk presented by their own mortality. Accident victims who did not die prematurely inevitably found that their compensation eventually would prove too little.

To counter these criticisms the concept of a structured settlement was developed. ${ }^{65}$ It enabled seriously injured claimants to receive regular annuity-based payments which could be guaranteed to last for their lifetime. In addition, the payments were free of tax and could be protected against inflation in prices. Claimants receiving structured payments were relieved from the stress of having to invest and be responsible for a lump sum far greater than most people encounter in their lifetime. In spite of these benefits, expansion of structured settlements was hindered by a variety of factors, including the refusal of many professionals to give proper consideration to the merits of the alternative form of payment. This was aided by the fact that either of the parties unilaterally could veto any proposed settlement based on periodical payments. The result was that, largely through inertia, the lump sum retained its dominance.

However, this was changed by legislation which came into force in 2005 . The Courts Act removed the parties' veto and gave judges the power to impose a periodical payments order (PPO) even if it was against the wishes of either, or both, of the parties. ${ }^{66}$ A former President of the Association of Personal Injury Lawyers concluded that the legislation was "the most important development ever relating to the law of

\footnotetext{
${ }^{65}$ R. Lewis, Structured Settlements: The Law and Practice (London: Sweet and Maxwell, 1993), N. Bevan, T. Huckle and S. Ellis, Future Loss in Practice: Periodical Payments and Lump Sums (London: Butterworths, 2007) and the International Underwriting Association of London, Periodical Payments Order Study (2011) http://www.iua.co.uk/IUA_Test/Documents/Circulars_2010/Circulars_2011/Periodical_Payment_Orde $\underline{\text { rs } \quad \text { PPO Study.aspx }}$

${ }^{66}$ Courts Act 2003 s100 and s101 amending the Damages Act 1996. R. Lewis, 'The Politics and Economics of Tort Law: Judicially Imposed Periodical Payments of Damages' (2006) 69 Modern Law $\operatorname{Rev} 418$.
} 
damages. ${ }^{, 67}$ Judges are now required to consider making a PPO in any personal injury case which comes to court if it involves future pecuniary loss. Although only a small percentage of cases involve such future loss, these claims are responsible for a substantial amount of the overall damages bill: insurers have estimated that the top one per cent of cases account for 32 per cent of total monies paid to claimants. ${ }^{68}$

Defendants and their insurers are now faced with a much higher bill in these periodical payment cases. There are two reasons for this. The first relates to the way in which most of these arrangements are funded. To safely guarantee the lifetime payments liability insurers usually purchase annuities from life offices. This can prove much more expensive than paying lump sum damages partly because of lack of competition in supplying the annuities required. Arranging for PPOs could be costing liability insurers up to a third more than under the lump sum regime.

The second reason for the increased bill relates to the radical changes made to the way in which periodical payment damages are now assessed. Claimants have been given considerable incentives to choose PPOs over lump sums. The advantages derive from the fact that there is now no need to calculate what lump sum would be required in order to work out the value of the periodical payments to be made. Instead, using a "bottom-up" approach, the court must assess the claimant's needs for the future and then order that periodical payments matching those needs be paid irrespective of their capital cost. These annual payments do not have to be adjusted to take account of speculative estimates of the claimant's life expectancy. Nor do returns have to be forecast of the income that arises upon investment of the damages because the lump sum is simply not there to invest. Instead, the defendant must comply with the order to make the specified regular payments no matter how the market performs and even if the claimant lives longer than forecast. In contrast to the traditional lump sum system, therefore, it is the defendant rather than the claimant who is now exposed to an uncertain financial future by being burdened with the twin risks of investment return and mortality.

\footnotetext{
${ }^{67}$ Colin Ettinger (2005) 155 New Law J 525.

${ }^{68}$ Lord Chancellor's Department, Courts Bill: Regulatory Impact Assessment (November 2002) table 1.
} 
This can be explained further by noting that in the calculations needed for a PPO there is no place for the 'Ogden Tables.' ${ }^{69}$ That is, multipliers and discount rates are not used: no multiplier is required to reflect the period of years of the loss in order to convert it into an immediate capital amount; and no discount rate is needed to convert the future stream of financial losses into a capital sum representing present day values. As considered under a later heading, the discount rate continues to operate very harshly against claimants if they seek a lump sum. The rate has been set far too high and expects claimants to obtain an unrealistic return on their damages. By contrast, for PPOs defendants cannot take advantage of the artificially high estimate of investment return embedded in the discount rate for lump sums. Instead they can be ordered to provide annual payments irrespective of what this might cost as an equivalent capital sum. Furthermore, the order extends for an uncertain period - the rest of the claimant's life. The risks that arise which relate to both the investment return and the longevity of the claimant are thus entirely transferred to the defendant and this carries with it a substantial additional cost.

The final advantage of a PPO over a lump sum is that, following a key appellate decision, periodical payments can now be inflation proofed by being tied not just to the future rise in prices but to the rise in earnings. ${ }^{70}$ This is of considerable importance in ensuring that a claimant's care costs will continue to be met. This is because, in general, the wages of carers over time will significantly exceed price inflation and will considerably increase the bill for future care. As a result of the case which allowed for this wage inflation the number of cases involving PPOs has increased substantially. The additional care costs which defendants must now bear, together with those costs arising from the new investment and mortality risks described above, account for the considerable rise in the true value of damages in these serious injury cases.

\section{Recovery of State Benefits from Damages}

\footnotetext{
${ }^{69}$ Government Actuary's Department, Actuarial Tables For Use In Personal Injury And Fatal Accident Cases (London: The Stationery Office, $7^{\text {th }}$ ed 2011, and subsequent updates).

${ }^{70}$ Thompstone v Tameside and Glossop Acute Services NHS Trust [2008] EWCA Civ 5, [2008] 2 All

ER 553. R. Lewis, 'The Indexation of Future Payments in Tort: The Future Assured?' (2010) 30 Legal Studies 391.
} 
Since 1990 defendants and their insurers have had to pay more for claims because they have had to reimburse the state for certain benefits received by the claimant as a result of the injury suffered. ${ }^{71}$ The state has been able to recover some of the cost of its social security expenditure and health care costs: public finances have thus been replenished. There are limits on the amounts that can be recovered. For example, money can only be sought for benefits received up to the date that a case settles; social security and NHS treatment provided later are at public expense. Another limit is that there is a maximum sum payable for health treatment. However, over the years the recovery scheme has proven effective in clawing back increasing amounts of money, especially following the inclusion of health service charges in 1999. By the new millennium the amount of social security recovered had risen steadily and had reached $£ 201$ million a year. Since then, caused partly by a marked decline in work accidents, the amounts recovered have fallen by a third so that in 2013-14 only $£ 134$ million was recouped. ${ }^{72}$ However, to this must also be added the health service charges recovered for that year of $£ 223$ million so that in total $£ 357$ million was repaid to the public purse. Unlike social security, these health service costs have increased year on year and now constitute the more important source of revenue. Even so, they represent but a tiny fraction of the actual expenditure on the NHS.

The recovery scheme has clearly increased the cost of claims, added to the premiums charged by insurers and thus contributed to one of the concerns about compensation culture. However, its effect upon the number of claims brought varies. Because the NHS is freely available, claimants are not directly affected by charges made to compensators for health costs. By contrast, the recovery of social security benefit has affected them. This is because the scheme enables compensators to reduce the damages that claimants can obtain from them by the amount of social security benefit that has to be repaid to the state. Damages have thus been reduced and, as a consequence, the incentive to claim.

\footnotetext{
${ }^{71}$ R. Lewis, 'Recovery of State Benefits From Tort Damages: Legislating For or Against the Welfare State?' in T. T. Arvind and J. Steele, Tort Law and the Legislature (2012) (Oxford: Hart Publishing) 285. R. Lewis, Deducting Benefits from Damages for Personal Injury (Oxford: OUP, 2000).

${ }^{72}$ Above n 6.
} 
However, the incentive was restored somewhat when the scheme was changed to exempt the claimant from any reduction in that part of the damages award which is paid for non-pecuniary loss. This means that no reduction in damages is to be made, even if a claimant receives benefits, provided that no financial loss has been suffered because, for example, earnings have been unaffected and there has been no need to pay for treatment or care. The compensation then is for pain and suffering alone and there can be no reduction. This is so even though the compensator remains liable to repay the social security benefits the claimant has received. In effect, such claimants have the whip hand in negotiations and can force advantageous settlements. They can emphasise that the longer the claim remains unpaid the larger will be the bill for benefits even though this will not reduce the amount of damages to be paid. The result is that insurers are encouraged settle certain claims promptly and at the higher end of the potential scale of payment. Predominantly these claims involve minor injury such as whiplash where it is often the case that the only compensation to be awarded is for pain and suffering. The recovery of benefits scheme can thus affect aspects of compensation culture.

\section{Non-Pecuniary Loss and Increasing the Price of Pain}

In practice, it is the compensation paid for pain and suffering that often provides the financial incentive to claim. In many cases it is the only head of personal injury damage that is sought. In recent years this compensation has increased significantly. There are a number of reasons for this, the most important being the changes made as a result of the test case of Heil $v$ Rankin. ${ }^{73}$ The judges in that case took the opportunity to raise awards for pain, suffering and loss of amenity in two ways: firstly, they increased payments for more serious injuries by up to a third; and secondly, they tied all awards in future to the rise in the Retail Prices Index. This second measure has accounted for a further rise in damages of about quarter since the test case was decided. Irrespective of whether the policy reasons given in the case justified these increases, ${ }^{74}$ it is clear that damages for non-pecuniary loss have risen substantially as a result. For example, at the top end of the scale, damages for severe

\footnotetext{
${ }^{73}$ [2000] EWCA Civ 84, [2001] QB 272.

${ }^{74}$ R. Lewis, 'Increasing the Price of Pain: Damages, the Law Commission and Heil v Rankin' (2001) 64 Modern Law Rev 100.
} 
brain damage or tetraplegia have increased from $£ 150,000$ at the turn of the century to about $£ 330,000$ today.

Damages have also risen as a result of the introduction and extensive use of the Judicial College's Guidelines for the Assessment of Damages in Personal Injury Cases. ${ }^{75}$ This is a book to be "packed in every judge's lunch bag"76 for it provides the parameters within which awards for pain and suffering are to be assessed. It is a two way process in as much as it informally guides courts but also tries to reflect their most recent decisions on quantum. First issued in 1991, it has been revised almost every two years and is now in its twelfth edition. It has become increasingly detailed. The booklet has been very helpful to practitioners and has removed some of the uncertainty that traditionally clouds the negotiation process. However, there can still be major disputes on the facts of cases, for example, in deciding which of the nine specified levels of neck injury the claimant has actually suffered. Subject to notable exceptions the regular revision of the booklet has generally resulted in a real increase in the scale of awards for particular injuries. In addition, the inflation update has ensured that practitioners have recent figures ready to hand which was not always the case in the past. On the whole, claimants have benefitted. To counteract this, insurers now want practitioners to be forced to assess pain and suffering by using computer software which values claims by incorporating information about the mass of settled claims instead of only the few that are adjudicated in court. ${ }^{77}$ Despite the successful political lobbying by insurers in recent years, the prospect of displacing the Judicial Guidelines with a calibration tool that insurers have devised seems very remote.

A final cause of increasing damages in this area relates to the changes in funding introduced as a result of Jackson reforms. ${ }^{78}$ Claimants have been compensated for no

\footnotetext{
75 Judicial College, Guidelines for the Assessment of Damages in Personal Injury Cases (Oxford: OUP, 12th ed 2013)

${ }^{76}$ Tony Weir, A Casebook on Tort (London: Sweet and Maxwell, 9th ed 2000) 637.

${ }^{77}$ Association of British Insurers, Evidence to Transport Committee (HC 902) above n 4. Similarly in its evidence the Forum of Insurers Lawyers wanted to limit the rise in low value claims in the Guidelines.

${ }^{78}$ R. Jackson LJ, Review of Civil Litigation Costs: Final Report (London: Judiciary of England and Wales, January 2010), and R. Jackson LJ, Civil Litigation Costs Review - Preliminary Report by Lord Justice Jackson (London: Judiciary of England and Wales, May 2009).
} 
longer being able to recover from defendants two items of expenditure: first, the success fee charged by their solicitor; and second, the premium that was paid for after the event insurance which was bought to protect against the risk of costs should the case be lost. In return for claimants bearing these extra pecuniary costs themselves, their damages for non-pecuniary loss have been increased by ten per cent. ${ }^{79}$ On the surface this seems an odd method of compensation for it substitutes apples for the loss of pears: that is, it increases the pain and suffering award when it is a financial loss that has been suffered. Even though the rough justice involved in devising this equivalent has some empirical support, it emphasises the peculiar prominence that pain and suffering now occupies within the tort system.

Let us take this point further. The overall increase in this head of claim is especially significant because the largest component of damages for personal injury is the payment made for pain and suffering: two thirds of the total damages awarded by the system are for non-pecuniary loss. ${ }^{80}$ The reason for this dominance lies in the fact that the tort system overwhelmingly deals with small claims, the great majority leading to damages of less than $£ 5,000 .^{81}$ In these cases claimants suffer very little, if any, financial loss from their bodily injury. They make a full recovery and have no continuing ill effects. The typical injury involves a whiplash, neck injuries of some sort accounting for four out of five claims in the system. ${ }^{82}$ Apart from recovering the cost of damage to the vehicle, the claim is usually only brought to recover the compensation for pain and suffering. In many cases, therefore, non-pecuniary loss

\footnotetext{
${ }^{79}$ Confirmed by Simmons v Castle [2012] EWCA Civ 1039.

${ }^{80}$ Pearson Commission above n 6, vol 2 table 107. The Health and Safety Executive similarly estimated that the cost of including pain and suffering would increase payroll costs from $1 \%$ to $2.5 \%$ in an integrated compensation scheme for work injury. Greenstreet Berman, Changing Business Behaviour - Would Bearing the True Cost of Poor Health and Safety Performance Make a Difference? (2002).

${ }^{81}$ In a survey of conditional fee claimants in 2011 half of them received less than $£ 5,000$. Insight Delivery Consultancy, No Win No Fee Usage in the UK appendix 5 of the Access to Justice Action Group, Comments on Reforming Civil Litigation Funding http://www.accesstojusticeactiongroup.co.uk/home/wp-content/uploads/2011/05/NWNF-research.pdf The average payment for non-pecuniary loss for cases settled within the claims portal was reported as $£ 2,300$ in January 2014.

${ }^{82}$ Above n 14.
} 
provides the only incentive to sue for personal injury. It is the engine that drives the tort system. By contrast, it also accounts for much of the disproportionate cost of the litigation system and it provides opportunities for exaggeration of losses and fraudulent claims. As such, it is the root cause of many of the concerns about compensation culture.

\section{Pecuniary Loss, Discount Rates and the Real Financial World}

The final reason accounting for a rise in the level of damages is that the tort award is wedded to the principle of returning the claimant to the position enjoyed before the injury took place insofar as it is possible to do so. ${ }^{83}$ In trying to give practical effect to this often merely rhetorical aim, judges have been forced in recent years to confront the realities of the financial world. This has led to a substantial increase in damages especially in cases of serious injury. Various examples of this are given below.

One of the most notable ways in which the practice of personal injury litigation differs from that of a generation ago is in the extensive use of expert evidence. In serious injury cases experts have been employed in areas which extend far beyond the traditional medical fields. They now consider all aspects of the injured person's life and future needs. This relates to a second change in litigation practice: claim schedules are now much more comprehensive than they once were, partly because of the involvement of these experts. Lawyers have been able to specify in considerable detail what the claimant will require in the future. With expert help, they have been able to place more precise monetary figures on what it costs to meet these needs. This level of detail and accounting, prompted by the avowed aim of making full reparation, has inevitable led to an increase in the value of claims. ${ }^{84}$

One group of experts who have been crucial in the construction of these detailed schedules are the financial analysts. Actuarial evidence is now accepted in courts in

\footnotetext{
83 'The only principle of law is that the claimant should receive full compensation for the loss he has suffered as a result of the defendant's tort, not a penny more but not a penny less,' (per Lady Hale, Simon v Helmot [2012] UKPC 5 at para 60).

${ }^{84}$ Ipsos Mori Research Institute, Personal Injury Discount Rate Research (2013) 24, Ministry of Justice Analytical Series. The author was the consultant for this research.
} 
ways not thought possible years ago. ${ }^{85}$ It was not by accident that forensic accountants proved more important in establishing and developing structured settlements than lawyers or judges. ${ }^{86}$ Very recently labour market economists have been added to the personal injury financial team. Their role has been pivotal, for example, in establishing that periodical payments can be tied not merely to the rise in prices but to wages, thus adding considerably to the value of such an award. ${ }^{87}$

A major contribution of these financial experts has been to refine the 'Ogden Tables, ${ }^{88}$ the actuarial tables devised especially for personal injury cases in order to compute pecuniary losses. Two recent examples will suffice to illustrate how changes to these tables have led to further increases in damages. Firstly, successive reforms have been made to allow for projected increases in mortality. We now live significantly longer than our forebears and this improvement is expected to continue into the future. Future mortality figures rather than those based on historic mortality are now used and these substantially increase damages, for example, for loss of pension rights especially where the claimant is young. These life expectancy gains can have a considerable effect in certain serious injury cases. Advances in medicine and support services have been such that paraplegics, for example, can today generally expect only a small reduction in their life expectancy. As a result, lifetime awards of damages have had to be increased to continue to allow for such matters as the length of time that future care will be needed.

A second change made to the tables relates to the allowance made for the prospective potential earning capacity of a disabled claimant. Research has demonstrated that people with disabilities spend more time out of employment than previously thought. ${ }^{89}$ As a result a higher discount is now applied to increase their damages so as

\footnotetext{
${ }^{85}$ Such evidence was made admissible by the Civil Evidence Act 1995. Contrast Auty v National Coal Board [1985] 1 WLR 784 where Oliver LJ stated that 'the predictions of an actuary could be only a little more likely to be accurate (and would almost certainly be less entertaining) than those of an astrologer'.

${ }^{86}$ R. Lewis, 'Structured Settlements: An Emergent Study' (1994) 13 Civil Justice Quarterly 18.

${ }^{87}$ Above $\mathrm{n} 70$.

${ }^{88}$ Above n 69.

${ }^{89}$ R. Lewis, R. McNabb, H. Robinson, and V. Wass, 'Court Awards of Damages for Loss of Future Earnings: An Empirical Study and an Alternative Method of Calculation' (2002) 29 J Law \& Society
} 
to account for their particular difficulties in the labour market. Acceptance of the value of such economic and social science data has been an important factor in raising damages awards.

In spite of the increase in damages which has taken place this century, it remains the case that claimants are very unlikely to receive 'full' compensation; they are not returned to the position they were in before the accident. The experience of past decades has proven that, for those who need long term care and support, the lump sum will prove insufficient. Few claimants injured in their youth have any compensation left when they enter old age today. There are several reasons for this but perhaps the most important is that too much allowance has been made for the potential return which can be obtained by a claimant by investing the damages. A discount rate is used to allow for the fact that the claimant receives compensation earlier than he would have had done so, for example, if he had been required to work for the wages now lost. The discount recognises that investment income can be obtained from this accelerated receipt of money. However, the rate used to calculate the damages has consistently been wrongly set; the figure has never reflected the true investment return that the claimant can actually achieve. ${ }^{90}$

For thirty years, until 1998, the discount rate was fixed at $4.5 \%$ in spite of a myriad of changes which took place in the financial world during that time. No matter when claimants invested, it was nearly always impossible to obtain the set return. Net interest and capital gain fell well short of what was required and this led to rapid depletion of the long-term value of the compensation. Today the legal system expects a claimant to achieve a real rate of return above inflation and after taxation of $2.5 \%$.

406, and by the same authors 'Loss of Earnings Following Personal Injury: Do the Courts Adequately Compensate Injured Parties?' (2003) 113 Economic Journal 568. These publications eventually led to the revision of the Ogden tables, above n 69, in order to take more account of the impact of disability on future employment.

${ }^{90}$ See also the above discussion of periodical payment orders. The introduction to the Government Actuary's Department, Actuarial Tables for use in Personal Injury and Fatal Accident Cases $\left(5^{\text {th }}\right.$ ed 2004) para 15 noted that the set discount rate had never been within $0.5 \%$ of the correct rate of return. The resulting substantial under-compensation is illustrated in the introduction to R. de Wilde et al, Facts and Figures $\left(13^{\text {th }}\right.$ ed 2008 - 2009). See also the comments of the former Government Chief Actuary, Chris Daykin, 'Fair Compensation Needs Actuaries' [2009] JPIL 48. 
With inflation at $2 \%$ and taxation costs at a further $1 \%$, in effect the claimant must obtain a return of $5.5 \%$ at a time when the best secure savings rate is far below that figure. It is inevitable that any lump sum awarded will be eroded much more quickly than the court presumes.

The present discount rate was set by the Lord Chancellor in 2001 and was based on the return on index linked government stocks (ILGS). Since then there has been a severe decline in the return from these gilt investments. Despite this, the $2.5 \%$ discount rate has remained unchanged and has become increasingly anachronistic. The real rate of return after inflation is traced in the below table. Even making no allowance for liability to tax, the returns have been far below $2.5 \%$.

\begin{tabular}{|c|c|c|}
\hline Year & $\begin{array}{c}\text { ILGS \% Yield } \\
\text { after inflation }\end{array}$ & $\begin{array}{c}\text { Real Yield } \\
\text { after tax \& inflation }\end{array}$ \\
\hline $\mathbf{2 0 0 1}$ & 2.4 & 2.11 \\
\hline $\mathbf{2 0 0 3}$ & 1.7 & 1.33 \\
\hline $\mathbf{2 0 0 7}$ & 1.6 & \\
\hline $\mathbf{2 0 0 9}$ & 1.4 & \\
\hline $\mathbf{2 0 1 1}$ & 0.6 & \\
\hline $\mathbf{2 0 1 3}$ & 0.0 & \\
\hline
\end{tabular}

To illustrate the dramatic effect a change in the discount rate can have upon an award of damages let us take the case of injury to a young person and an earning loss calculated to last for 40 years:

- Applying the old 4.5\% rate the multiplier for the annual loss would be 18.4;

- for the present $2.5 \%$ rate it is 24.85 , an increase in damages of $35 \%$;

- and if the discount rate is reduced to nil so as to reflect the real investment return today on ILGS the multiplier is 38.85 , an increase in damages of $111 \%$ since the $4.5 \%$ rate was last used in $1998 .^{91}$

For many years claimant lawyers lobbied for the discount rate to be revised but they had little success. However, in 2012 the Ministry of Justice issued a consultation

${ }^{91}$ Simon v Helmot [2012] UKPC 5 dramatically illustrates the potential effect of lowering the discount rate. It concerned the long term care of a young victim of a Guernsey road accident. Because of the jurisdiction, the court was not bound by the specified $2.5 \%$ discount rate and instead based the decision upon common law principles. As a result the total award was almost $£ 14$ million and the difference between the cost of future care using a 2.5 per cent discount rate and the minus 1.5 per cent rate actually used was £5.25 million. See A. Lewis ‘Discount Rates’ [2012] JPIL 40. 
paper asking how the rate should be set. ${ }^{92}$ Insurers were particularly alarmed by the prospect of a change in the discount rate and emphasised that in practice claimants did not actually invest in ILGS. After effective lobbying, the Ministry were persuaded that further investigation was required and a second consultation paper was issued dealing with the legal framework. ${ }^{93}$ Although this may have the effect of limiting any downward pressure upon the discount rate, it is the change threatened in this area that could potentially have the greatest effect on defendants and the overall cost of the tort system. ${ }^{94}$ The Ministry at present is sitting on its hands and two years after consultation closed it has yet to respond. ${ }^{95}$

\section{CONCLUSION}

In reviewing compensation culture this chapter has focused upon the number of claims and the cost of claims. Although motor claims have doubled this century, largely because of institutional factors and a "dysfunctional insurance market," other claims have remained relatively stable. By contrast the cost of claims has continued to increase, albeit for reasons which many supporters of the tort system would support. Much of the increase in compensation can be attributed to the overall aim of returning the claimant, as far as possible, to the position enjoyed before personal injury was suffered. As that principle is developed further, with courts increasingly using financial expertise to assist in the calculations, it can be anticipated that levels of damages in serious injury cases will continue to rise. As a result, current compensation culture issues, together with the reforms in the legal profession which much influence them, will continue to be debated for some time to come.

\footnotetext{
${ }^{92}$ Ministry of Justice, Damages Act 1996: The Discount Rate - How Should it be Set? Consultation Paper CP12/2012.

${ }^{93}$ Ministry of Justice, Damages Act 1996: The Discount Rate - Review of the Legal Framework Consultation Paper CP3/2013.

${ }^{94}$ For the most recent analysis see E. Tomlinson, 'The Discount Rate: What Options Does the Lord Chancellor Have?' [2014] JPIL 255.

${ }^{95}$ In a letter to the Association of Personal Injury Lawyers in August 2014 the Justice Secretary, Chris Grayling, saw no reason to publish a timetable setting out when the decision might be taken.
} 